\title{
KEKUTAN HUKUM AKTA PERJANJIAN PENGIKATAN JUAL BELI TANAH (STUDI DI DESA BABAKAN KECAMATAN SANDUBAYA KOTA MATARAM)
}

\author{
GEDE TUSAN ARDIKA ${ }^{1)}$, RAMLI') \\ Fakultas Hukum UNMAS Mataram \\ e-mail: ${ }^{1)}$ gedetusan@gmail.com, ${ }^{2)}$ ramli@yahoo.com
}

\section{ABSTRAK}

Penelitian ini bertujuan untuk mengetahui: bentuk perlindungan hukum bagi para pihak akibat hukum dari pembatalan akta pengikatan jual-beli tanah dan faktor-faktor yang melatar belakangi terjadinya pembatalan akta pengikatan jual-beli tanah di Desa Babakan Kecamatan Sandubaya Kota Mataramt.

Jenis penelitian ini adalah penelitian normatif-empiris, dengan metode pendekatan perundangundangan (the statute approach), pendekatan konseptual, pendekatan analisis kasus (case approach) dan pendekatan fakta. Sumber bahan hukum yang digunakan berupa bahan hukum primer, bahan hukum sekunder dan bahan hukum tersier. Pengumpulan data lapangan menggunakan teknik wawancara, kemudian dianalisis kualitatif.

Dari hasil penelitian dapat disimpulkan bahwa 1) Kekuatan hukum dari akta perjanjian pengikatan jual beli hak atas tanah yang dibuat oleh Notaris dalam pelaksanaan pembuatan Akta Jual-Belinya adalah sangat kuat.karena merupakan akta notaril yang bersifat akta otentik, 2) Akibat-akibat hukum yang timbul dari pembatalan akta Pengikatan Jual Beli Tanah: (a) Para pihak dapat dikenakan denda yang besarnya telah disepakati dari jumlah yang harus dibayar pembeli kepada penjual atau pembeli, untuk tiap-tiap hari keterlambatan. Denda tersebut harus dibayar dengan seketika dan sekaligus, (b) Perjanjian berakhir dan sepanjang perlu kedua belah pihak melepaskan diri dari apa yang ditetapkan dalam Pasal 1266 dan Pasal 1267 Kitab Undang-Undang Hukum Perdata, danPihak Penjual wajib untuk mengembalikan uang yang telah dibayarkan oleh Pihak Pembeli setelah dipotong beberapa persen dari harga jual tanah dan bangunan tersebut sebagai pengganti biaya yang telah dikeluarkan oleh Pihak Penjual ditambah denda yang harus dibayar oleh Pihak Pembeli kepada Pihak Penjual.

Kata kunci: pengikatan akta, pembatalan dan akibat hukumnya

\section{ABSTRACT}

This study aims to determine: the form of legal protection for the parties due to the law from the cancellation of the land purchase agreement and the factors underlying the cancellation of the binding deed of sale and purchase of land in Babakan Village, Sandtubaya District, Mataramt City.

This type of research is normative-empirical research, using the statute approach, conceptual approach, case analysis approach (case approach) and fact approach. The sources of legal material used are in the form of primary legal materials, secondary legal materials and tertiary legal materials. Field data collection using interview techniques, then analyzed qualitatively.

From the results of the study, it can be concluded that 1) The legal strength of the sale and purchase rights agreement on land rights made by a Notary in the implementation of the Deed of Sale and Purchase is very strong. Because it is an authentic deed, 2) Legal consequences arises from the cancellation of the Land Purchase Sale deed: (a) The parties may be liable to a fine which has been agreed upon from the amount that must be paid by the buyer to the seller or buyer, for each day of delay. These fines must be paid instantly and at once, (b) The agreement ends and insofar as both parties need to break away from what is stipulated in Article 1266 and Article 1267 of the Civil Code, and the Seller Party is obliged to return the money paid by the Party The buyer after deducting a few percent from the selling price of the land and building in lieu of the costs incurred by the Selling Party plus the fine that must be paid by the Purchaser to the Seller.

Keywords: binding of deed, cancellation and legal consequences 


\section{PENDAHULUAN}

\section{Latar Belakang}

Pentingnya bukti pemilihan hak atas tanah sebagai wujud kepastian hukum hak atas tanah. Akta Otentik dari penjualan tanah harus dimiliki oleh setiap orang atau badan hukum yang menguasai tanah sebab akta jual beli tanah adalah bukti penguasaan pemilikan has atas tanah yang bersifat kuat, sehingga tidak dapat diganggu-gugat oleh pihak-pihak lainnya. Pemilikan tanah berarti jika ditinjau dari aspekwaktu/lamanya seseorang dapat mempunyai/menguasai tanah sesuai dengan isikewenangan dari hak atas tanah tersebut, maksudnya pemegang hak atas tanahdilindungi dari gangguan baik dari sesama warga negara dalam bentuk misalnyapenguasaan ilegal ataupun dari penguasa. Pada dasarnya jika pihak lainmemerlukan tanah untuk keperluan apapun, maka cara untuk memperoleh tanahyang diperlukan harus dilalui dengan cara musyarah dengan pemegang hak atastanah hingga tercapai kata sepakat yang benar-benar keluar dari maksud baikantara kedua belah pihak yang bersangkutan.

Hak atas tanah merupakan hak yang melekat yang tidak dapat dihilangkan begitu saja. Hak atas tanah akan diperoleh setelah melakukan suatu transaksi misalnya jual beli. Meskipun telah dilakukan transaksi jual-beli atas tanah, tidak secara otomatis hak atas tanah beralih kepada pembeli, karena terlebih dahulu harus melalui tahapan-tahapan tertentu agar kepemilikan tanah dapat beralih dari pihak yang satu ke yang lain.

Akta jual-beli tanah yang ditandatangani para pihak membuktikan telah terjadi pemindahan hak dari penjual. Pemilikan atas tanah dapat memberikan manfaat dan kegunaan dalam berbagai aspek kepada pemiliknya, baik dalam aspek ekonomi, aspek sosial, termasuk dalam hubungannya dengan pembangunan.

Terkadang persyaratan untuk membuat Akta Jual Beli belum dapat terpenuhi karena berbagai sebab yaitu tanah yang dibeli belum mempunyai sertifikat sehingga masih dalam proses pengurusan atau obyek jual beli belum dapat terbayar lunas oleh pembeli, untuk mengatasi hal tersebut dapat dibuat Perjanjian Pengikatan Jual Beli (PPJB). PPJB merupakan perjanjian pendahuluan sebelum dilakukannya perjanjian jual beli melalui Akta Jual Beli (AJB).

Apabila suatu akta hendak memperoleh stempel otentisitas, hal mana terdapat pada akta otentik, maka menurut ketentuan dalam pasal 1868 KUHPerdata, akta yang bersangkutan harus memenuhi persyaratanpersyaratan berikut :

1. Akta itu harus dibuat "oleh" (door) atau "dihadapan" (ten overstaan) seorang pejabat umum.

2. Akta itu harus dibuat dalam bentuk yang ditentukan oleh undang-undang.

3. Pejabat umum oleh atau dihadapan siapa akta itu dibuat, harus mempunyai wewenang untuk dibuat akta itu.

Kadang kala karena suatu hal seseorang itu dapat membatalkan apa yang telah ia berikan kepada orang lain yang karena tidak terpenuhinya prestasi. Begitu dengan Hibah dan Jual beli yang haknya sudah dialihkan kepada orang lain atau bahkan anaknya sendiri dicabut atau menariknya kembali, yang dimaksud mencabut dan menariknya kembali adalah membatalkan hibah dan jual beli.

Diantara perjanjian-perjanjian lainnya, Perjanjian Pengikatan Jual Beli (PPJB) yang paling berpotensi konflik adalah akta PPJB yang obyeknya tentang peralihan hak atas tanah, misalnya seperti para pihak tidak memberikan keterangan yang benar tentang keadaan obyek perjanjian, apakah obyek tersebut dalam keadaan sengketa atau tidak, pihak penjual menjual tanah tidak dengan persetujuan istri / suami, pihak penjual memberikan surat keterangan waris yang keliru, atau bisa juga ditimbulkan karena kekhilafan/kesalahan notaris itu sendiri, misalnya notaris memihak pada salah satu pihak yang membuat perjanjian, tidak mencantumkan batas waktu perjanjian dalam akta sehingga hal-hal tersebut menimbulkan permasalahan bagi para pihak yang membuat perjanjian.

Dalam praktek kenotariatan PPJB telah sering dipergunakan, namun sebenarnya perjanjian pengikatan jual beli (PPJB) tidak pernah diatur dalam peraturan perundangan-undangan yang berkaitan dengan hak atas tanah, sehingga sering menimbulkan konflik dalam pelaksanaan jual beli hak atas tanah. Salah satunya kasus PPJB ganda yang dibuat Notaris di Desa Babakan Kecamatan Sandubaya Kota Mataram yang menimbulkan akibat kerugian pada salah satu pembelinya, dimana kasus seperti ini jarang terjadi. Oleh karena itu penulis tertarik untuk melakukan penelitian yang lebih lanjut mengenai proses hukum yang dapat dilakukan oleh pembeli yang dirugikan, serta sejauh mana tanggung jawab hukum notaris, yang akan dituangkan dalam tulisan yang berjudul "Kekuatan Hukum Akta Perjanjian Pengikatan Jual Beli Tanah (Studi di Desa Babakan Kecamatan Sandubaya Kota Mataram)" 


\section{Rumusan Masalah}

adalah:

Berdasarkan latar belakang tersebut di atas, maka permasalahan yang akan diajukan oleh penulis

1. Bagaimana kekuatan hukum akta perjanjian pengikatan jual beli tanah di Desa Babakan Kecamatan Sandubaya Kota Mataram?

2. Bagaimana akibat hukum dari pembatalan akta pengikatan jual beli tanah di Desa Babakan Kecamatan Sandubaya Kota Mataram?

\section{Tujuan dan Manfaat Penelitian}

Tujuan penelitian ini adalah untuk mengetahui kekuatan hukum akta perjanjian pengikatan jual beli tanah dan akibat akibat hukum dari pembatalan akta pengikatan jual beli tanah di Desa Babakan Kecamatan Sandubaya Kota Mataram. Hasil penelitian ini diharapkan bermanfaat : dapat memberikan masukan yang sangat berharga bagi berbagai pihak mengenai pembatalan akta pengikatan jual beli tanah.

\section{METODE PENELITIAN}

Penelitian merupakan penelitian normatif-empiris. Dimana pendekatan yuridis normatif yaitu penelitian yang menggunakan bahan pustaka atau data sekunder yang terdiri dari bahan hukum primer,bahan hukum sekunder dan bahan hukum tersier sebagai bahan utama. Pendekatan terhadap hukum yang normatif mengindentifikasikan dan menkonsepsikan hukum sebagai norma, kaidah, peraturan, undang-undang yang berlaku. Sedangkan pendekatan empiris dilakukan dengan mengkaji kasus yang terjadi di lapangan. khususnya gambaran lengkap dan jelas tentang akibat hukum dari pembatalan pengikatan jual beli akta tanah tersebut.

Dalam hal ini dipergunakan data sekunder yang diperoleh dari perpustakaan, yaitu berupa peraturan perundang-perundangan, keputusan pengadilan, teori-teori hukum normatif dan pendapat para sarjana terkemuka dibidang ilmu hukum.Penelitian kepustakaan dilakukan dengan cara mencari dan mengumpulkan serta meneliti bahan pustaka yang merupakan data sekunder yang berhubungan dengan judul dan pokok permasalahan.

Teknik pengumpulan data melalui wawancara dan pengumpulan bahan hukum, kemudian dianalisis dengan menggunakan analisis kualitatif yaitu mengumpulkan data, mengualifikasikan, kemudian menghubungkan teori yang berhubungan dengan masalah dan akhirnya menarik kesimpulan untuk menentukan hasil.

\section{HASIL PENELITIAN DAN PEMBAHASAN}

\section{Kekuatan Hukum Akta Perjanjian Pengikatan Jual Beli Tanah di Desa Babakan Kecamatan Sandubaya Kota Mataram.}

Dalam Peraturan Pemerintah Nomor 24 Tahun 1997 tentang Pendaftaran Tanah dan Peraturan Pemerintah Nomor 37 Tahun 1998 tentang Peraturan Jabatan Pembuat Akta Tanah (PPAT), diatur bahwa dalam melakukan jual-beli hak atas tanah harus dilakukan di hadapan pejabat yang berwenang, Selain itu akta pemindahan haknya (akta jual belinya) juga dibuat oleh Pejabat Pembuat Akta Tanah (PPAT) dan akta jual-beli tersebut merupakan akta otentik yang bentuk dan isinya berdasarkan peraturan perundang-undangan yang berlaku.

Sebelum melakukan jual-beli dihadapan Pejabat Pembuat Akta Tanah (PPAT), pihak-pihak yang akan melakukan jual-beli harus memenuhi persyaratan-persyaratan yang diatur dalam pelaksanaan jual-beli tanah. Persyaratan tentang objek jual belinya, misalnya hak atas tanah yang akan diperjual belikan merupakan hak yang sah yang dimiliki dan di buktikan dengan adanya sertifikat tanah atau tanda bukti sah lainnya. Serta tanah yang di perjual belikan tidak berada dalam sengketa dengan pihak lain, dan sebagainya.

Disamping itu jual-beli telah dibayar secara lunas dan semua pajak yang berkaitan dengan jual-beli seperti pajak penjual (SSP) dan pajak pembeli yaitu (Bea Perolehan Hak Atas Tanah dan Bangunan/BPHTB) juga telah dilunasi oleh pihak yang akan melakukan jual-beli. Setelah semua hal tersebut dilengkapi atau terpenuhi, barulah para pihak yang akan melakukan jual-beli tanah dapat melakukan jual-beli hak atas tanah 
dan pembuatan akta jual-beli tanah di hadapan Pejabat Pembuat Akta Tanah (PPAT) serta selanjutnya melakukan pendaftaran tanah untuk pemindahan haknya.

Namun apabila persyaratan-persyaratan tersebut belum dipenuhi maka pembuatan dan penandatanganan terhadap akta jual beli hak atas tanah belum bisa dilakukan di hadapan Pejabat Pembuat Akta Tanah (PPAT), karena itu Pejabat Pembuat Akta Tanah (PPAT) akan menolak untuk membuatkan akta jual belinya sebagai akibat belum terpenuhinya semua syarat tentang pembuatan akta jual beli (AJB), yang dengan sendirinya jual beli hak atas tanah belum bisa dilakukan.

Kondisi tersebut tentu saja tidak menguntungkan para pihak yang melakukan jual beli hak atas tanah. Pihak penjual di satu sisi harus menunda proses penjualan tanah sampai semua syarat tersebut bisa dipenuhi. Bagi pihak pembeli, keinginannya untuk mendapatkan hak atas tanah harus tertunda.

Untuk mengatasi hal tersebut, dan guna kelancaran tertib administrasi pertanahan maka dibuatlah Akta Pengikatan Jual Beli (PJB), yang mengatur tentang jual beli tanah. Namun format APJB hanya sebatas pengikatan jual beli yaitu suatu bentuk perjanjian penduhuluan sebelum dilakukannya perjanjian jual beli sebenarnya.

Perjanjian Pengikatan Jual Beli (PJB) merupakan sebuah terobosan hukum yang dilakukan oleh kalangan Notaris untuk mengatasi permasalahan yang dihadapi dalam pelaksanaan jual-beli hak atas tanah sebagaimana telah diterangkan sebelumnya. Penemuan hukum yang dilakukan dan diterapkan oleh Notaris tentang pemakaian perjanjian Pengikatan Jual Beli (PJB) dalam membantu pelaksanaan jualbeli hak atas tanah atau sebagai perjanjian pendahuluan sebelum pembuatan Akta Jual Beli bukanlah sesuatu hal yang melanggar ketentuan dan norma hukum yang ada, sehingga Pengikatan Jual Beli (PJB) sah untuk diterapkan dan dipakai. Karena penemuan hukum bertujuan untuk memecahkan masalah-masalah hokum rumit dan melewati proses yang panjang.

Posisi Pengikatan Jual Beli (PJB) yang merupakan sebuah penemuan hukum yang belum diatur dalam peraturan perundang-undangan. Semua perbuatan hukum yang menyangkut tanah harus mengkuti peraturan perundang-undangan. Dengan keadaan tersebut maka dapat disimpulkan bahwa akta pengikatan jual beli dapat berlaku dua kedudukan tergantung bagaimana perjanjian Pengikatan Jual Beli (PJB) itu dibuat.

Pengertian dari akta otentik diterangkan dalam Pasal 1868 Kitab Undang-undang Hukum Perdata yang berbunyi: "Suatu Akta Otentik ialah suatu akta yang di dalam bentuk yang ditentukan oleh Undang-undang di buat oleh atau dihadapan pegawai-pegawai umum yang berkuasa untuk itu ditempat dimana akta dibuatnya."

Berdasarkan Pasal 1868 Kitab Undang-undang Hukum Perdata tersebut di atas dapatlah dilihat bahwa untuk akta otentik bentuk dari aktanya ditentukan oleh Undang-undang dan harus dibuat oleh atau dihadapan Pegawai yang berwenang. Pegawai yang berwenang yang dimaksud disini antara lain adalah Notaris, hal ini di dasarkan pada ketentuan Pasal 1 angka 1 Undang-undang nomor 1 tahun 2004 tentang Jabatan Notaris yang menyatakan bahwa Notaris adalah Pejabat Umum yang berwenang untuk membuat akta otentik dan berwenang lainnya sebagai dimaksud dalam Undang-undang ini.

Jadi sesuai dengan aturan dalam Pasal 1868 Kitab Undang-undang Hukum Perdata ditetapkan atau dapat dinyatakan bahwa syarat untuk akta otentik adalah sebagai berikut:

a. akta harus dibuat "oleh" (door) atau " dihadapan " (ten overstaan) seorang pejabat umum;

b. akta harus dibuat dalam bentuk yang ditentukan oleh Undang-undang;

c. pejabat umum oleh atau dihadapan siapa akta itu dibuat, harus mempunyai wewenang untuk membuat akta itu.

Dari keterangan di atas terlihat bahwa pada Pengikatan Jual Beli (PJB), yang dibuat dihadapan atau oleh Notaris maka akta perjanjian Pengikatan Jual Beli (PJB) menjadi sebuah akta yang otentik. Karena telah dibuat dihadapan atau oleh pejabat yang berwenang (salah satunya Notaris) sehingga telah memenuhi ketentuan atau syarat tentang akta otentik yaitu akta itu harus dibuat "oleh" (door) atau "dihadapan" (ten overstaan) seorang pejabat umum.

Hal yang sama juga diungkapkan oleh Notaris Rizul Sudarmadi, SH., yang penulis wawancarai pada tanggal 26 Januari 2019, menyatakan bahwa Pengikatan Jual Beli (PJB) pada dasarnya merupakan perjanjian dibawah tangan, hanya saja jika dilakukan atau dibuat oleh atau di hadapan pejabat umum yang berwenang, yaitu Notaris, maka menjadi akta notaris yang bersifat akta otentik. Sedangkan apabila pengikatan jual beli tidak dibuat di hadapan pejabat umum maka Pengikatan Jual Beli (PJB) menjadi akta di bawah tangan, dan untuk Akta dibawah tangan lebih lanjut diatur dalam Pasal 1874 Kitab Undang-undang Hukum Perdata 
Pasal tersebut bermaksud mengatur akta dibawah tangan yang baru mempunyai kekuatan pembuktian kepada Pihak Ketiga apabila setelah dibuat pernyataan di depan Notaris, caranya adalah dengan menandatangani akta tersebut dihadapan Notaris atau pejabat yang ditunjuk untuk pengesahan tanda tangan.

Dari keterangan di atas terlihat bahwa untuk Pengikatan Jual Beli (PJB) yang tidak dibuat di hadapan pejabat umum atau akta dibawah tangan baru mempunyai kekuatan terhadap pihak ketiga antara lain apabila dibubuhi suatu pernyataan yang bertanggal dari seorang Notaris atauseorang pegawai lain yang ditunjuk oleh Undang-undang sebagaimana diatur dalam Pasal 1874 dan Pasal 1880 Kitab Undang-undang Hukum Perdata.

Dalam pelaksanaannya, perjanjian pengikatan jual-beli tidak memerlukan pengesahan sebagiamana diterangkan di atas, karena perjanjian pengikatan jual-beli biasanya dibuat di hadapan Notaris yang merupakan Pejabat Umum, sehingga akta yang dibuat terhadap pengikatan jual beli tersebut telah menjadi akta otentik sehingga pembuktiannya sangat kuat.

Berdasarkan uraian tersebut maka dapat disimpulkan bahwa kekuatan hukum dari akta perjanjian pengikatan jual beli hak atas tanah yang dibuat oleh Notaris dalam pelaksanaan pembuatan Akta Jual Belinya mempunyai kekuatan hukum. Hal ini karena pada Pengikatan Jual Beli (PJB) yang dibuat dihadapan notaris, aktanya telah menjadi akta notaril sehinga merupakan akta otentik, sedangkan untuk yang dibuat tidak dihadapan notaris maka menjadi akta dibawah tangan yang pembuktiannya berada dibawah akta otentik, walaupun dalam Pasal 1875 Kitab Undang-undang Hukum Perdata memang disebutkan bahwa akta dibawah tangan dapat mempunyai pembuktian yang sempurna seperti akta otentik apabila tanda tangan dalam akta tersebut diakui oleh para pihak yang menanda tanganinya.

Namun ketentuan dalam Pasal 1875 Kitab Undang-undang Hukum Perdata menunjuk kembali Pasal 1871 Kitab Undang-undang Hukum Perdata yang menyatakan bahwa akta dibawah tangan dapatlah menjadi seperti akta otentik namun tidak memberikan bukti yang sempurna tentang apa yang termuat didadalamnya, karena akan dianggap sebagai penuturan belaka selain sekedar apa yang dituturkan itu ada hubungan langsung dengan pokok isi akta.

Jadi kekuatan hukum yang ada dalam perjanjian pengikatan jual-beli hanyalah tergantung dimana perjanjian pengikatan jual-beli dibuat, jika bukan dihadapan pejabat umum (notaris) maka menjadi akta dibawah tangan sedangkan jika dibuat oleh atau dihadapan pejabat umum maka akta tersebut menjadi akta notariil yang bersifat akta otentik.

\section{Akibat Hukum Pembatalan Akta Perjanjian Pengikatan Jual Beli Tanah di Desa Babakan Kecamatan Sandubaya Kota Mataram}

Dalam perjanjian pengikatan jual-beli merupakan sebuah perjanjian pendahuluan, maka biasanya di dalam perjanjian pengikatan jual-beli tersebut akan termuat janji janji dari para pihak yang mengandung ketentuan-ketentuan atau syarat-syarat yang apabila semua ketentuan tersebut atau syarat-syarat tersebut telah dipenuhi maka jual-beli hak atas tanah yang disepakati dalam perjanjian pengikatan jual-beli dapat dilakukan.

Akan tetapi ada kemungkinan dalam melaksanakan semua persyaratan yang disepakati dalam perjanjian pengikatan jual-beli bisa saja terjadi membutuhkan waktu yang cukup lama, sehingga ada kemungkinan juga untuk calon penjual berhalangan untuk melakukan penandatanganan terhadap akta jual belinya (AJB).

Hal ini tentunya akan menimbulkan kesulitan bagi pihak pembeli karena ketika semua persyaratan dan ketentuan yang disepakati dalam perjanjian pengikatan jual-beli telah dipenuhi pihak penjual berhalangan untuk melakukan penandatanganan terhadap akta jual belinya, sehingga pemindahan hak tidak bisa dilakukan padahal pihak pembeli telah memenuhi semua kewajiban untuk memperoleh haknya sebagaimana telah disepakati dalam perjanjian pengikatan jual-beli.

Untuk menghindari hal tersebut biasanya pihak pembeli dalam perjanjian pengikatan jual-beli akan meminta dibuatkan sebuah surat kuasa dari bakal penjual yang didalamnya termuat ketetuan apabila pihak penjual berhalangan hadir sedangkan semua syarat dan ketentuan yang disepakati dalam perjanjian pengikatan jual-beli telah terpenuhi, sehingga telah bisa dilakukan penandatanganan terhadap akta jual beli, maka penjual biasanya akan memberikan kuasa kepada pembeli untuk menghadap sendiri dan menandatangani akta jual beli atas nama penjual di hadapan Notaris.

Dengan kata lain berdasarkan kuasa tersebut maka pihak pembeli dapat menghadap dan menandatangani Akta Jual Beli (AJB) secara sendiridi hadapan Notaris baik sebagai penjual maupun sebagai 
pembeli. Hal ini karena pihak penjual telah memberikan kuasa kepada pihak pembeli apabila dia berhalangan maka pihak pembeli dapat melakukan sendiri panandatanganan tersebut.

Dalam konteks Hukum Perjanjian Indonesia menurut KUH Perdata, terdapat beberapa alasan untuk membatalkan perjanjian. Alasan itu dapat dikelompokkan ke dalam lima kategori sebagai berikut:

a. Tidak terpenuhinya persyaratan yang ditetapkan oleh undag-undang untuk jenis perjanjian formil. yang berakibat perjanjian batal demi hukum.

b. Tidak terpenuhinya syarat sahnya perjanjian, yang berakibat; 1) Perjanjian batal demi hukum. Atau 2) Perjanjian dapat dibatalkan;

c. Terpenuhinya syarat batal pada jenis perjanjian bersyarat;

d. Pembatalan oleh pihak ketiga atas dasar action paulina;

e. Pembatalan oleh pihak yang diberi kewenangan khusus berdasarkan undang-undang.

Apabila perjanjian batal demi hukum artinya dari semula tidak pernah dilahirkan suatu perjanjian, dan dengan demikian tidak pernah ada suatu perikatan. Sedangkan arti dari perjanjian yang dapat dibatalkan dimaksudkan apabila perjanjian tersebut tidak memenuhi unsure subjektif untuk sahnya perjanjian sebagaimana diatur dalam pasal $1320 \mathrm{KUH}$ Perdata, yaitu kesepakatan pada pihak dan kecakapan para pihak untuk melakukan perbuatan hukum, sedangkan pejabat yang dapat membuatnya tidak dapat dihindarkan agar berbobot yang sama harus pula ditentukan oleh undang-undang atau peraturan perundang-undang setingkat dengan undang-undang.

Menurut ketentuan pasal 1266 ayat (1) KUHPerdata, syarat batal dianggap tercantum dalam perjanjian timbal-balik, apabila salah satu pihak dalam perjanjian tersebut mengingkari apa yang telah diperjanjikan. Pasal 1266 ayat(2) KUHPerdata menyatakan bahwa untuk membatalkan suatu perjanjian harus dengan putusan hakim. Selanjutnya pasal 1266 ayat (3) KUHPerdata menegaskan bahwa permintaan pembatalan tersebut harus dilakukan meskipun syarat batal telah dicantumkan dalam perjanjian. Dlam Praktik dilapangan para pihak yang membuat suatu perjanjian seing mengabaikan ketentuan pasal 1266 ayat (2) tersebut.

Akta tersebut membuktikan bahwa benar telah dilakukan perbuatan hukum pemindahan hak untuk selama-lamanya dan pembayaran harganya. Karena perbuatan hukum yang dilakukan merupakan perbuatan hukum pemindahan hak, maka akta tersebut membuktikan bahwa penerima hak (pembeli) sudah menjadi pemegang haknya yang baru.Pembatalan yang diputuskan oleh hakim pengadilan Negari atas suatu akta PPAT dapat terbentuk batal demi hukum (van rechtswege neiting) atau dapat dibatalkan (van rechtswege neiting) atau dapat dibatalkan (verniettigbear), apabila suatu akta dari PPAT tidak memenuhi persyaratan yang telah ditentukan oleh undang-undang (pasal 1320 Kitab Undang-undang Hukum Perdata), yaitu apabila tidak memenuhi syarat subyektif ( sepakat mereka yang mengikatkan dirinya, cakap untuk berbuat sesuatu perjanjian) dan syarat objektif (suatu dasar pertimbangan tersebut Hakim Pengadilan Negeri dapat membatalkan suatu akat PPAT dalam bentuk batal demi hukum apabila tidak memenuhi syarat objektif atau dapat dibatalkan apabila tidak memenuhi syarat subyektif.

Akibat-akibat hukum yang timbul dari pembatalan akta Pengikatan Jual Beli Tanah: (1) Para pihak dapat dikenakan denda yang besarnya telah disepakati dari jumlah yang harus dibayar pembeli kepada penjual atau pembeli, untuk tiap-tiap hari keterlambatan. Denda tersebut harus dibayar dengan seketika dan sekaligus, (2) Perjanjian berakhir dan sepanjang perlu kedua belah pihak melepaskan diri dari apa yang ditetapkan dalam Pasal 1266 dan Pasal 1267 Kitab Undang-Undang Hukum Perdata, danPihak Penjual wajib untuk mengembalikan uang yang telah dibayarkan oleh Pihak Pembeli setelah dipotong beberapa persen dari harga jual tanah dan bangunan tersebut sebagai pengganti biaya yang telah dikeluarkan oleh Pihak Penjual ditambah denda yang harus dibayar oleh Pihak Pembeli kepada Pihak Penjual.

Pengembalian uang oleh Pihak Penjual kepada Pihak Pembeli dilakukan selambat-lambatnya dalam jangka waktu tertentu yang telah disepakati, misalnya 21 (dua puluh satu hari) hari setelah tanah dan bangunan tersebut terjual kepada pihak lain.

Untuk menyatakan batalnya suatu perbuatan hukum, kita temukan istilah-istilah "batal demi hukum", "membatalkannya" (Pasal 1449 KUHPerdata), "menuntut pembatalan" (Pasal 1450 KUHPerdata), "pernyataan batal" (Pasal 1451-1452 KUHPerdata), "gugur" (Pasal 1545 KUHPerdata), "gugur demi hukum" (Pasal 1553KUHPerdata).

Ajaran kebatalan berlaku atas semua perbuatan hukum baik perbuatan hukum berganda maupun tindakan hukum sepihak. Dengan mengatakan suatu perbuatan hukum batal, berarti bahwa karena adanya cacat hukum mengakibatkan tujuan perbuatan hukum tersebut menjadi tidak berlaku. Akibat kebatalan berlaku pula terhadap beding yang batal, keputusan yang batal atau wasiat yang batal. Pada perbuatan 
hukum dapat mengandung cacat yang sifat cacat tersebut dapat berbeda-beda. Dengan adanya cacat yang berbeda menimbulkan sanksi yang berbeda pula. Perbedaan utama mengenai kebatalan adalah batal demi hukum (van rechtswege nietig) dan dapat dibatalkan (vernietigbaar).

Perbuatan hukum yang mengandung cacat namun penentuan apakah perbuatan hukum tersebut menjadi sah atau batal tergantung pada keingingan orang tertentu menyebabkan perbuatan hukum tersebut dapat dibatalkan.

Sebagaimana diketahui untuk suatu perjanjian harus dipenuhi unsur perjanjian yaitu: (1) Adanya kata sepakat diantara dua pihak atau lebih, (2) Kata sepakat yang tercapai tergantung pada paru pihak, (3) Kemauan para pihak untuk timbulnya akibat hukum, (4) Akibat hukum untuk kepentingan yang satu atas beban pihak yang lain atau timbal balik, dan (5) Dengan mengindahkan persyaratan perundang-undangan. Apabila pembeli digugat atas wanprestasi karena tidak melakukan prestasinya secara penuh yaitu salah satunya dengan tidak mengosongkan/menyelesaikan pemberesan atas tanah seluas 150 M2 yang masih dikuasai dan ditempati oleh pihak ketiga, sedangkan pihak pembeli yang digugat wanprestasi oleh pihak penjual karena tidak melakukan pembayaran.

Pihak penjual yang melakukan wanprestasi sudah diperingatkan atau sudah dengan tegas ditagih janjinya dan tetap tidak melakukan prestasinya, maka tersebut berada dalam keadaan lalai atau alpa, terhadapnya dapat diberikan sanksi-sanksi. Akan tetapi, karena wanprestasi mempunyai akibat-akibat yang begitu penting, maka harus ditetapkan lebih dahulu apakah pihak tersebut melakukan wanprestasi dan kalau hal itu disangkal olehnya, pihak Pembeli harus membuktikannya di muka hakim.

Dalam acara pembuktian baik pembeli dan penjual mengajukan peristiwa dan fakta-fakta yang menjadi dasar bagi gugatan Pembeli atau jawaban Penjual. Peristiwa-peristiwa tersebut harus diikuti dengan bukti-bukti yang sah menurut hukum untuk dapat dipastikan kebenarannya. Pasal 163 HIR menyatakan

"Barang siapa yang mengatakan ia mempunyai hak, atau ia menyebutkan suatu perbuatan untuk menguatkan haknya itu atau untuk membantah hak orang lain, maka orang itu harus membuktikan adanya hak itu atau adanya kejadian itu." Dalam hal ini yang harus dibuktikan yaitu peristiwa, kejadian, dan hak tertentu, bukan hukumnya."

Dalam ketentuan Pasal 164 HIR dinyatakan, yang disebut alat-alat bukti yaitu: bukti dengan, surat/tertulis; bukti dengan saksi; persangkaan-persangkaan; pengakuan dan sumpah

Alat bukti tertulis dari pihak pembeli pada kasus antara yang diajukan sebagai salah satu bukti bahwa telah terjadi kesepakatan ialah perjanjian pengikatan jual beli tanah yang diwaarmeking oleh Notaris.Dan pada kasus antara, misalnya, Esther dan Fadhul Bari bukti bahwa telah terjadi kesepakatan dalam bentuk tertulis adalah perjanjian pengikatan jual beli tanah yang dibuat dihadapan Notaris, sehingga perjanjian itu merupakan akta otentik. Perjanjian Pengikatan Jual Beli dibawah tangan merupakan salah satu dari alat bukti sebagaimana tersebut dalam pasal 164 HIR, mempunyai kekuatan pembuktian sempurna selama diakui oleh para pihak yang membuat perjanjian. Selama pemeriksaan perkara baik pihak pembeli maupun pihak penjual tidak membantah atas kebenaran tanda tangan pada perjanjian pengikatan jual beli tanah. Maka sudah tentu perjanjian tersebut mengikat kedua belah pihak.

Berdasarkan bukti-bukti yang diajukan oleh kedua belah pihak, terkait dalil gugatan yang diajukan oleh pihak penjual yaitu pihak pembeli tidak melakukan kewajibannya untuk melakukan pembayaran fakta yang terjadi ialah pihak pembeli telah melakukan sejumlah pembayaran sebesar Rp. 50.000.000,- sebelum perjanjian pengikatan jual beli tanah dibuat yaitu pada tanggal 16 November 2016. Dan pada tanggal 17 November 2016 para pihak membuat perjanjian pengikatan jual beli tanah dibawah tangan yang ditandatangani oleh para pihak dan dikatakan pula perjanjian tersebut berlaku juga sebagai kwitansi pembayaran yang sah. Dan pada pembayaran selanjutnya diberikan dengan bukti tertulis yaitu kwitansi pembayaran yang sah.

Diketahui pada fakta persidangan dalam perjanjian pengikatan jual beli atas tanah tersebut terdapat klausula mengenai denda jika pihak penjual ingkar janji melakukan kewajibannya. Namun tidak didapati kalusula yang mengatur apabila pihak pembeli yang melakukan ingkar/wanprestasi. Sehingga hal ini menunjukkan perjanjian pengikatan jual beli tersebut lebih menguntungkan pihak pembeli terutama soal saksi bila pihak penjual lalai/ingkar janji (wanprestasi).

Menurut hukum perjanjian bahwa harus ada keseimbangan antara para pihak yang melaksanakan perjanjian. Dengan tidak adanya klausula yang memuat bagaimana bila pihak pembeli telah ingkar janji/wanprestasi. Perjanjian pengikatan jual beli yang dibuat oleh para pihak memiliki ketidak 
seimbangan dengan ditunjukkan tidak adanya perlindungan hukum bagi pihak penjual jika pihak pembeli telah lalai/ingkar janji dengan kewajibannya.

Berdasarkan fakta yang dibenarkan oleh saksi yang diajukan oleh pihak pembeli bahwa pihak pembeli telah beritikad baik melakukan yaitu melakukan pelunasan pembayaran terhadap harga obyek perkara sebagaimana yang telah disepakati namun pihak penjual menolak untuk menerima pelunasan tersebut. Sedangkan dalil penjual yang menyatakan bahwa pihak pembeli telah melakukan wanprestasi tidak dibenarkan karena terdapat bukti-bukti tulis berupa kwitansi yang menunjukkan bahwa pihak penjual telah menerima pembayaran atas harga jual tersebut. Maka dalam hal ini yang melakukan wanprestasi pada kasus ini adalah pihak penjual dengan tidak memenuhi prestasinya dan melakukan wanprestasi dengan tidak melakukan apa yang disanggupi memenuhi perikatan yaitu dengan tidak melakukan pengosongan terhadap tanah seluas $150 \mathrm{M} 2$ yang masih dikuasai oleh pihak ketiga.

Pada perkara ini perjanjian pengikatan jual beli atas tanah secara dibawah tangan yang dibuat oleh pembeli dan para Penjual telah dilakukan Waarmeking di Notaris Lalu Mulyadi, SH. seorang notaris memiliki kewenangan untuk melakukan waarmerking terhadap suatu perjanjian dibawah tangan. Perjanjian dibawah tangan yang telah memperoleh waarmeking dari notaris kekuatan pembuktiannya tidak dapat dipersamakan dengan akta otentik, sebab akta otentik hanyalah akta yang dibuat oleh pejabat berwenang yang ditunjuk oleh undang-undang dalam hal ini adalah notaris.

Waarmerking ialah pengesahan tanggal dari perjanjian/akta dibawah tangan oleh Notaris atau pejabat umum lainnya yang ditunjuk oleh undang-undang dengan dilakukannya pendaftaran tanggal surat-surat yang dibuat dibawah tangan dalam buku register. Pada waarmeking tidak ada kepastian tanda tangan para pihak yang membuat perjanjian, sebelum disampaikan kepada notaris yang bersangkutan. Maka dimungkinkan tanggal ditandatanganinya suatu perjanjian tidaklah sama saat didaftarkan kepada notaris. Waarmerking hanya memberi pembuktian kepada Pihak Ketiga mengenai kebenaran tanggal pendaftaran tapi tidak memberikan pembuktian mengenai tanda tangan para pihak dalam perjanjian.

\section{SIMPULAN DAN SARAN}

\section{Simpulan}

1.Kekuatan hukum dari akta perjanjian pengikatan jual beli hak atas tanah yang dibuat oleh notaris dalam pelaksanaan pembuatan Akta Jual Belinya adalah sangat kuat, karena akta tersebut merupakan akta notaris yang bersifat akta otentik, pemberian kuasa yang tidak dapat ditarik kembali dalam perjanjian pengikatan jual beli bukanlah termasuk ke dalam kuasa mutlak yang dilarang oleh Intruksi Menteri Dalam Negeri Nomor 14 Tahun 1982 tentang Larangan Penggunaan Kuasa Mutlak Sebagai Pemindahan Hak Atas Tanah, sehingga status hukumnya sah-sah saja untuk dilakukan.

2. Akibat-akibat hukum yang timbul dari pembatalan akta Pengikatan Jual Beli Tanah: (1) Para pihak dapat dikenakan denda yang besarnya telah disepakati dari jumlah yang harus dibayar pembeli kepada penjual atau pembeli, untuk tiap-tiap hari keterlambatan. Denda tersebut harus dibayar dengan seketika dan sekaligus, (2) Perjanjian berakhir dan sepanjang perlu kedua belah pihak melepaskan diri dari apa yang ditetapkan dalam Pasal 1266 dan Pasal 1267 Kitab Undang-Undang Hukum Perdata, danPihak Penjual wajib untuk mengembalikan uang yang telah dibayarkan oleh Pihak Pembeli setelah dipotong beberapa persen dari harga jual tanah dan bangunan tersebut sebagai pengganti biaya yang telah dikeluarkan oleh Pihak Penjual ditambah denda yang harus dibayar oleh Pihak Pembeli kepada Pihak Penjual.

\section{Saran-saran}

1. Sebaiknya mengenai pengikatan jual beli diatur lebih lanjut dalam peraturan perundang-undangan terutama yang berkaitan dengan masalah tanah, sehingga para pihak yang memakai pengikatan jual beli sebagai perjanjian pendahuluan dalam jual beli hak atas tanah lebih terlindungi dengan baik.

2. Untuk para Notaris dalam pembuatan Akta Pengikatan Jual Belinya harus secara tegas menuliskan dalam pasal-pasalnya tentang klausul mengenai wanprestasi sehingga para pihak baik penjual maupun pembeli memperoleh perlindungan hukum. 


\section{DAFTAR PUSTAKA}

Bambang Sugono, 1997. Metodologi Penelitian Hukum, Raja Grafindo Jakarta

GHS Lumban Tobing, 1992. Peraturan Jabatan Notaris, Erlangga Jakarta.

Gunawan Widjaja dkk, 2004. Jual Beli. PT Raja Grafindo Persada Jakarta

J. Satrio, 1995. Hukum Perikatan, Perikatan yang Lahir dari Perjanjian, PT. Citra Aditya Bakti Bandung

Lexy J. Moelong, 2007. Metodologi Penelitian Kualitatif Edisi Revisi. Remaja Rosdakarya Bandung.

Liliana Tedjasaputro, 1991. Etika Profesi Hukum, Aneka Ilmu. Semarang

M. Yahya, 1986. Segi-segi Hukum Perjanjian. Alumni. Bandung

Muhammad Adam, 1995. Asal Usul dan Sejarah Notaris, Sinar Baru Bandung

R. Setiawan, 1987. Pokok-Pokok Hukum Perikatan: Binacipta Bandung

R. Subekti, 2001. Hukum Pembuktian. Pradnya Paramita Jakarta

Soerjono, Soekanto dan Sri Mamudji, 2006. Penelitian Hukum Normatif. Raja Grafindo Persada Jakarta

Sudaryo Soimin, 1994. Status Tanah dan Pembebasan Tanah, Sinar Grafika Jakarta

Sugiyono, 2010. Metode Penelitian Administrasi. Alfabeta Bandung

Suhrawadi K. Lubis, 1994. Etika Profesi Hukum. Sinar Grafika Jakarta

Supriadi, 2006. Etika \& Tanggung Jawab Profesi Hukum di Indonesia. Sinar Grafika Jakarta

Tobing Lumban, 1996. Peraturan Jabatan Notaris, Cet. Ketiga, Erlangga Jakarta

Wawan Setiawan, 2004. Notaris Profesional, Media Notariat, Edisi Mei-Juni 2004. 